\title{
PENERAPAN AKUNTANSI PERTANGGUNGJAWABAN BIAYA PRODUKSI SEBAGAI ALAT PENILAIAN PRESTASI MANAJER PRODUKSI PADA PDAM KABUPATEN MALANG
}

\author{
ZURAIDAH \\ Jurusan Akuntansi Fakultas Ekonomi \\ Universitas Islam Negeri Maulana Malik Ibrahim Malang \\ J1. Gajayana No. 50, Tlp 0341-558881, Fax. 0341-558881 \\ e-mail: Idazuraidah94@yahoo.co.id
}

\begin{abstract}
Report would assist management in assessing whether each responsibility center has carried out his duties in accordance with the predetermined budget. Implementation of good accounting would create a system of control and performance assessment which will assist management in decision making. Accounting can also provide the basis to conduct an evaluation of the ability of all levels of management within the company. Once the importance of accounting information for the management of production costs as a tool to assess the performance and production manager as well as an attempt to direct the company's activities so that the goal can be achieved. Responsibility accounting is one of the concepts of accounting and management accounting systems are linked and adapted to the responsibility centers that exist in the organization. Istliah responsibility accounting will lead to accounting reporting process to how best to responsibility center managers can manage the work under the direct supervision and responsibility or who is a system that measures and action plans of each responsibility center.
\end{abstract}

Keywords : responsibility accounting, cost of production, the production manager

\begin{abstract}
Abstrak
Laporan pertanggungjawaban akan membantu pimpinan dalam menilai apakah setiap pusat pertanggungjawaban telah melaksanakan tugasnya sesuai dengan anggaran yang telah ditetapkan sebelumnya. Penerapan akuntansi pertanggungjawaban yang baik akan menciptakan suatu sistem pengendalian dan penilaian prestasi yang nantinya akan membantu pimpinan dalam pengambilan keputusan. Akuntansi pertanggungjawaban juga dapat memberikan dasar untuk mengadakan evaluasi atas kemampuan setiap tingkatan manajemen dalam
\end{abstract}


perusahaan. Begitu pentingnya keberadaan informasi akuntansi pertanggungjawaban biaya produksi bagi pimpinan sebagai alat untuk menilai prestasi manajer produksi dan juga sebagai upaya untuk mengarahkan kegiatan sehingga tujuan perusahaan dapat tercapai. Akuntansi pertanggungjawaban merupakan salah satu konsep dari akuntansi manajemen dan sistem akuntansi yang dikaitkan dan disesuaikan dengan pusat-pusat pertanggungjawaban yang ada dalam organisasi. Istilah akuntansi pertanggungjawaban ini akan mengarah pada proses akuntansi yang melaporkan sampai bagaimana baiknya manajer pusat pertanggungjawaban dapat memanage pekerjaan yang langsung dibawah pengawasannya dan yang merupakan tanggung jawabnya atau suatu sistem yang mengukur rencana dan tindakan dari setiap pusat pertanggungjawaban.

Kata kunci: akuntansi pertanggungjawaban, biaya produksi, manajer produksi.

Adanya pendelegasian wewenang memberikan manfaat bagi perusahaan. Manfaatnya adalah memungkinkan masalah yang besar dan rumit dikelompokkan menjadi bagian yang lebih terkelola sehingga membantu manajer menengah ke bawah dalam pengambilan keputusan dan menyediakan suatu dasar untuk mengevaluasi kinerja dalam pengambilan keputusan.

Selain itu dengan adanya pendelegasian wewenang masing-masing manager mempunyai tanggung jawab atas unit kerjanya. Dalam suatu perusahaan unit kerja yang dipimpin oleh seorang manajer yang bertanggungjawab disebut pusat pertanggungjawaban. Tujuan dari suatu pusat pertanggungjawaban adalah dapat membantu pencapaian tujuan suatu organisasi atau perusahaan.

Seorang manager produksi yang memimpin bagian produksi bertanggungjawab untuk menghasilkan produk tertentu dengan biaya atau masukan serendah mungkin sehingga bagian produksi hanya merupakan pusat biaya. Dalam hal ini bagian produksi akan dinilai berhasil apabila dapat menekan biaya produksi yang dikeluarkan dalam kegiatan produksi. Oleh karena itulah manajemen dituntut untuk melakukan evaluasi atau pengukuran prestasi kerja manajer pusat pertanggungjawaban yang berada di bawah wewenangnya.

Laporan pertanggungjawaban akan membantu pimpinan dalam menilai apakah setiap pusat pertanggungjawaban telah melaksanakan tugasnya sesuai dengan anggaran yang telah ditetapkan sebelumnya. Penerapan akuntansi 
pertanggungjawaban yang baik akan menciptakan suatu sistem pengendalian dan penilaian prestasi yang nantinya akan membantu pimpinan dalam pengambilan keputusan. Akuntansi pertanggungjawaban juga dapat memberikan dasar untuk mengadakan evaluasi atas kemampuan setiap tingkatan manajemen dalam perusahaan.

Begitu pentingnya keberadaan informasi akuntansi pertanggungjawaban biaya produksi bagi pimpinan sebagai alat untuk menilai prestasi manajer produksi maka perlu dilakukan penelitian tentang akuntansi pertanggungjawaban biaya produksi dalam perusahaan sebagai upaya untuk mengarahkan kegiatan sehingga tujuan perusahaan dapat tercapai.

Gambar 1.

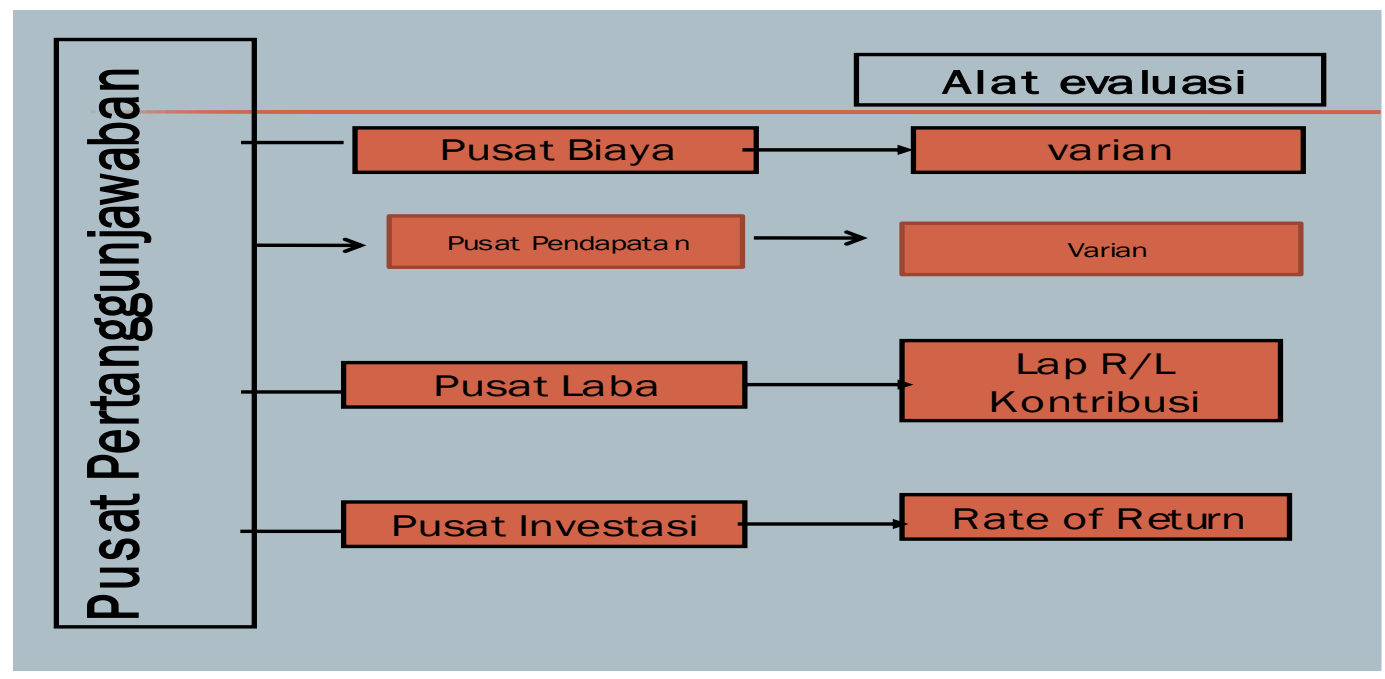

Sumber : Materi akuntansi pertanggungjawaban

Dalam penelitian ini penulis melakukan studi kasus pada Perusahaan Daerah Air Minum (PDAM) Kabupaten Malang. PDAM Kabupaten Malang merupakan perusahaan daerah yang memberikan pelayanan, melindungi dan memanfaatkan serta menyelenggarakan fasilitas umum yang ada di Kabupaten Malang. Pada perusahaan ini seorang direktur mendelegasikan tugas dan wewenang kepada manajemen yang ada di bawahnya. Hal ini menimbulkan tanggungjawab bagi manajemen bawah untuk mempertanggungjawabkan tugas dan wewenang kepada manajemen yang ada di atasnya. 
Gambar 2.

TIPE PUSAT PERTAN GGUNG JAWABAN
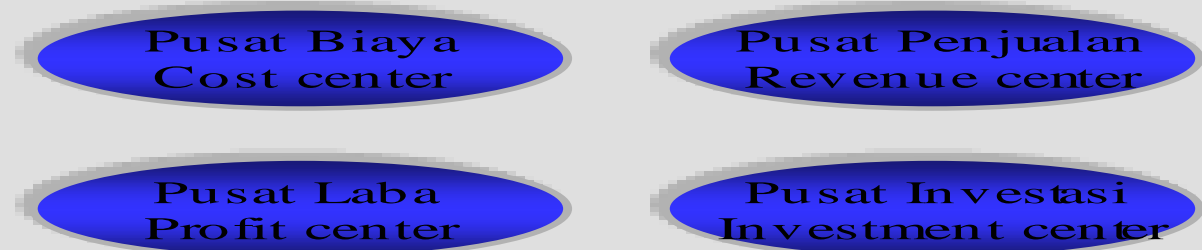

Profit center

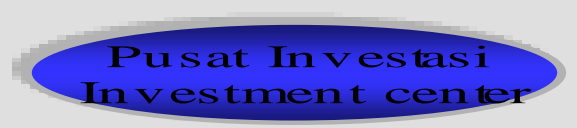

Sumber : Materi akuntansi pertanggungjawaban

\section{METODE}

Metode analisis yang digunakan dalam penelitian ini adalah metode kualitatif. Metode ini adalah metode analisa data dengan mengadakan penganalisaan terhadap hal-hal yang menimbulkan masalah dengan prosedur teoritis serta perkiraan dengan logis. Seperti ;

1. Analisis Struktur Organisasi

Tujuannya adalah untuk mengetahui apakah struktur organisasi yang ada telah sesuai dengan konsep akuntansi pertanggungjawaban dimana terdapat desentralisasi wewenang dan tanggung jawab yang tegas untuk setiap tingkatan manajemen.

2. Analisis Laporan Biaya Produksi

Tujuannya untuk mengetahui apakah laporan biaya tersebut mencantumkan anggaran dan realisasi biaya yang terjadi dan disusun menurut tingkatan manajemen pusat pertanggungjawaban.

3. Analisis Terhadap Penggolongan Biaya

Tujuannya untuk mengetahui apakah perusahaan sudah melakukan pemisahan dan penggolongan unsur-unsur biaya menjadi biaya terkendali 
dan biaya tidak terkendali, sehingga dapat diketahui siapa yang bertanggungjawab atas terjadinya biaya tersebut.

4. Analisis Kode Rekening Biaya

Tujuannya untuk mengetahui apakah klasifikasi biaya dan pengkodean rekening yang diterapkan telah sesuai dengan struktur organisasi yang ada sehingga mendukung penerapan akuntansi pertanggungjawaban.

5. Analisis Prestasi Kerja

Tujuannya untuk mengetahui prestasi kerja manajer produksi dengan membandingkan antara anggaran dengan realisasinya.

6. Melakukan Analisis Varians

Tujuannya untuk mempelajari dan menganalisa penyimpangan yang terkait dengan prestasi kerja manajer produksi dengan menggunakan analisis varians.

Gambar 3.

\section{Perkembangan Fokus Metode Pengendalian Biaya}

\begin{tabular}{|c|c|c|}
\hline \multicolumn{3}{|c|}{ SISTEM AKUNTANSI PERTANGGUNGJAWABAN } \\
\hline $\begin{array}{c}\text { TRADITIONAL RESPON. } \\
\text { ACC }\end{array}$ & $\begin{array}{l}\text { ACTIVITY BASED RESPON. } \\
\text { ACC }\end{array}$ & SISTEM BIAYA STANDAR \\
\hline $\begin{array}{c}\text { Fokus pengendalian } \\
\text { terhadap konsumsi } \\
\text { sumber daya oleh }\end{array}$ & $\begin{array}{c}\text { Fokns pengendalian } \\
\text { terhadap aktivitas yang } \\
\text { mengkonsumsi sumber daya }\end{array}$ & $\begin{array}{c}\text { Fok pongendalian pada } \\
\text { (product cost) }\end{array}$ \\
\hline
\end{tabular}

Nilai sumber daya yang dikonsumsi Merupakan biaya
Aktivitas mengkonsumsi sumber daya
Produk memerlukan aktivitas 


\section{HASIL DAN PEMBAHASAN}

\section{Pengertian Akuntansi Pertanggungjawaban}

Prestasi setiap manajer harus dinilai seberapa baik dan mampu ia mengelola hal-hal yang secara langsung berada di bawah pengendalian. Oleh karena itulah muncul adanya akuntansi pertanggungjawaban untuk mengetahui kinerja manajer tersebut dengan melihat pada anggaran dan realisasinya.

Sedangkan menurut Mulyadi (2001:218) akuntansi pertanggungjawaban adalah suatu sistem akuntansi yang disusun sedemikian rupa sehingga pengumpulan dan pelaporan biaya dan atau pendapatan dilakukan sesuai dengan pusat pertanggungjawaban dalam organisasi, dengan tujuan agar dapat ditunjuk orang atau kelompok yang bertanggungjawab atas penyimpangan biaya dan atau pendapatan yang dianggarkan.

Sulastiningsih dan Zulkifli (1999:278) menyebutkan bahwa akuntansi pertanggungjawaban adalah sistem yang mengukur rencana (dengan anggaran) dan tindakan (dengan hasil aktual) yang digunakan untuk menilai prestasi pusatpusat pertanggungjawaban.

Dari beberapa pengertian di atas dapat disimpulkan bahwa akuntansi pertanggungjawaban merupakan suatu sistem untuk menilai prestasi manajer pusat-pusat pertanggungjawaban dengan terlebih dahulu mengklasifikasikan secara seksama biaya dan pendapatan organisasi atau perusahaan sesuai dengan berbagai tingkatan manajemen. Setiap tingkatan manajemen hanya dibebani biaya yang berada dibawah pengendaliannya, dan manajer bertanggungjawab atas penyimpangan antara tujuan yang dianggarkan dengan hasil sesungguhnya.

\section{Ketenagakerjaan}

PDAM Kabupaten Malang memiliki tenaga kerja sebanyak 591 orang yang terdiri atas tiga orang bertindak selaku Direktur, 24 orang di Bagian Umum, 8 orang di Bagian Personalia, 11 orang di Bagian Keuangan, 10 orang di Bagian Pelanggan, 10 orang di Bagian Perencanaan, 11 orang di Bagian Produksi dan Distribusi, 11 orang di Bagian Peralatan, 1 orang di Bagian Poliklinik, 11 orang di 
staf SPI, 6 orang di bagian honorer SPI atau Satpam dan 5 orang di koperasi. Adapun pegawai yang lainnya tersebar di 23 unit PDAM Kabupaten Malang. Berikut ini data pegawai PDAM Kabupaten Malang berdasarkan unit kerja:

Tabel 1.

PDAM Kabupaten Malang Data Pegawai Berdasarkan Unit Kerja

\begin{tabular}{|c|c|c|c|c|}
\hline \multirow[b]{2}{*}{ No. } & \multirow[b]{2}{*}{ Nama Unit Kerja } & \multicolumn{2}{|c|}{ Keterangan } & \multirow{2}{*}{$\begin{array}{c}\text { Jumlah } \\
\text { (Orang) }\end{array}$} \\
\hline & & $\begin{array}{c}\text { Karyawan } \\
\text { (Orang) }\end{array}$ & $\begin{array}{c}\text { Karyawati } \\
\text { (Orang) }\end{array}$ & \\
\hline 1. & Unit Lawang & 34 & 16 & 50 \\
\hline 2. & Unit Singosari & 20 & 12 & 32 \\
\hline 3. & Unit Karangploso & 16 & 8 & 24 \\
\hline 4. & Unit Pujon & 14 & 2 & 16 \\
\hline 5. & Unit Ngantang & 7 & 2 & 9 \\
\hline 6. & Unit Kepanjen & 24 & 7 & 31 \\
\hline 7. & Unit Pakisaji & 19 & 9 & 28 \\
\hline 8. & Unit Bantur & 9 & 2 & 11 \\
\hline 9. & Unit Donomulyo & 10 & 1 & 11 \\
\hline 10. & Unit Ampelgading & 7 & - & 7 \\
\hline 11. & Unit Dampit & 13 & 3 & 16 \\
\hline 12. & Unit Turen & 15 & 3 & 18 \\
\hline 13. & Unit Gondanglegi & 15 & 3 & 18 \\
\hline 14. & Unit Bululawang & 15 & 4 & 19 \\
\hline 15. & Unit Tumpang & 13 & 5 & 18 \\
\hline 16. & Unit Sumbermanjing Wetan & 8 & 1 & 9 \\
\hline 17. & Unit Pakis & 25 & 8 & 33 \\
\hline 18. & Unit Poncokusumo & 14 & 7 & 21 \\
\hline 19. & Unit Tajinan & 17 & 3 & 20 \\
\hline 20. & Unit Ngajum & 10 & 4 & 14 \\
\hline 21. & Unit Jabung & 7 & 2 & 9 \\
\hline \multirow[t]{2}{*}{22.} & Unit Dau & 14 & 3 & 17 \\
\hline & Jumlah & 326 & 105 & 431 \\
\hline
\end{tabular}

Sumber : PDAM Kabupaten Malang (diolah) 


\section{Anggaran}

Penyusunan anggaran sangatlah penting bagi perusahaan. Di antaranya adalah untuk menentukan perkiraan seluruh pendapatan dalam tahun yang akan datang berdasarkan evaluasi dari pelaksanaan anggaran tahun sebelumnya. Selain itu anggaran juga digunakan sebagai pedoman untuk menentukan prioritas program kerja sesuai dengan kemampuan dana yang ada sehingga pelaksanaan kerja dapat mencapai hasil guna dan daya guna yang optimal.

Adapun proses penyusunan anggaran pada PDAM Kabupaten Malang adalah sebagai berikut:

\section{Bagan 2}

PDAM Kabupaten Malang

Bagan Proses Penyusunan Anggaran

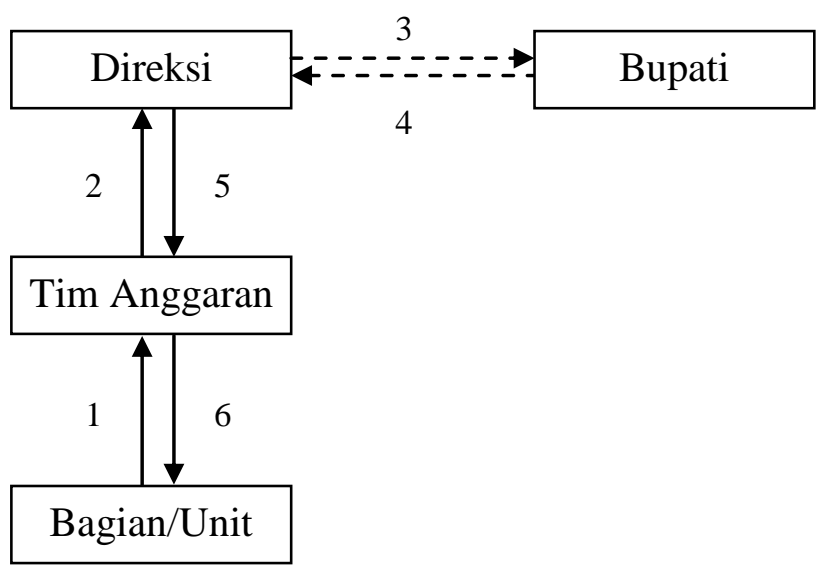

Sumber : PDAM Kabupaten Malang (diolah)

\section{Analisis Sistem Pelaporan Biaya}

Sistem pelaporan biaya dalam akuntansi pertanggungjawaban pada penelitian ini ditekankan untuk penilaian kerja manajer pusat biaya. Melalui laporan ini akan diketahui perbandingan antara anggaran dan biaya aktual.

Bentuk pelaporan yang sesuai dengan konsep akuntansi pertanggungjawaban menunjukkan adanya sistem pelaporan yang bergerak dari 
bawah ke atas yaitu bergerak dari pusat pertanggungjawaban yang terendah hingga pusat pertanggungjawaban yang tertinggi. Agar pelaporan biaya yang dilakukan memenuhi syarat yang diterapkan dalam akuntansi pertanggungjawaban maka perusahaan perlu membuat laporan pertanggungjawaban yang sesuai dengan struktur organisasi yang ada. Dalam laporan pertanggungjawaban harus menunjukkan adanya anggaran, realisasi dan penyimpangan-penyimpangan yang terjadi. Selain itu dalam penyusunan laporan pertanggungjawaban juga harus mengelompokkan biaya-biaya yang ada menurut dapat tidaknya biaya tersebut dikelompokkan oleh pusat biaya yang bersangkutan.

\section{Analisis Varian}

a. Varians Biaya Bahan Baku

1) Varians harga bahan

Varians harga bahan $=$ (harga per unit aktual - harga per unit standar) x kuantitas yang dibeli$$
=(\operatorname{Rp} 25.00-\operatorname{Rp} 25.00) \times \operatorname{Rp} 190.792
$$$$
=0
$$

2) Varians kuantitas bahan

Varians kuantitas bahan $=($ kuantitas aktual pemakaian - kuantitas standar yang dijalankan) $\mathrm{x}$ harga/unit standar

$$
=\left(934.5 \mathrm{~m}^{3}-946 \mathrm{~m}^{3}\right) \times \mathrm{Rp} 25
$$

$=\operatorname{Rp} 2787,5$

Dari perhitungan varians biaya bahan baku dapat diketahui bahwa selisih harga bahan adalah 0 (nol). Ini berarti bahwa perusahaan tidak mengalami laba atau keuntungan. Sedangkan untuk selisih kuantitas bahan mengalami keuntungan 
sebesar Rp 2787,5. Hal ini disebabkan karena kuantitas sesungguhnya yang dipergunakan lebih kecil daripada kuantitas standar yang disyaratkan.

b. Varian biaya tenaga kerja langsung

1) Penetapan tarif biaya tenaga kerja langsung

a) Tarif standar biaya tenaga kerja langsung $=\frac{\text { Jumlah anggaran biaya tenaga kerja langsung standar }}{\text { Jumlah jam kerja standar }}$

$$
\begin{aligned}
& =\frac{\operatorname{Rp} 2.040 .000 .000,00}{2.016} \\
& =\operatorname{Rp} 1.011 .904,762
\end{aligned}
$$

b) Tarif aktual biaya tenaga kerja langsung

$$
\begin{aligned}
& =\frac{\text { Jumlah biaya tenaga kerja langsung aktual }}{\text { Jumlah jam kerja aktual }} \\
& =\frac{\operatorname{Rp~} 1.641 .786 .304,00}{2.184}=\operatorname{Rp~751.733,656}
\end{aligned}
$$

2) Varians Biaya Tenaga Kerja Langsung

a) Varians Tarif Pekerja

$$
\begin{aligned}
\text { Varians tarif pekerja } & =(\text { tarif aktual pekerja }- \text { tarif standar } \\
& \text { pekerja }) \times \text { jam kerja aktual } \\
& =(\operatorname{Rp} 751.733,656-\mathrm{Rp} 1.011 .904,762) \mathrm{x} \\
& 2.184 \\
& =\operatorname{Rp} 568.213 .695,5 \mathrm{M}
\end{aligned}
$$

b) Varians efisiensi pekerja

$$
\begin{aligned}
\text { Varian efisiensi pekerja }= & (\text { jam kerja aktual }- \text { jam kerja standar }) \times \\
& \text { tarif pekerja standar } \\
= & (2.184-2.016) \times \mathrm{Rp} .1 .011 .904,762 \\
= & \operatorname{Rp} 170.000 .000(\mathrm{M})
\end{aligned}
$$

Dari hasil perhitungan varian tenaga kerja langsung dapat diketahui bahwa selisih tarif pekerja menguntungkan sebesar Rp 568.213.695,5. Hal ini disebabkan karena tarif yang sesungguhnya tidak melebihi tarif standar perusahaan. Sedangkan untuk selisih efisiensi pekerja juga menguntungkan 
perusahaan karena tarif yang sesungguhnya tidak melebihi tarif standar perusahaan.

c. Varian Overhead Pabrik

1) Penetapan tarif biaya overhead pabrik

a) Tarif biaya overhead pabrik

Tarif biaya overhead pabrik :

$=\frac{\text { Jumlah anggaran biaya overhead pabrik }}{\text { Jumlah jam standar }}$

$=\frac{\operatorname{Rp} 2.947 .204 .309,00}{2.016}$

$=\operatorname{Rp} 1.461 .906,89$

b) Tarif biaya overhead pabrik tetap

Tarif biaya overhead pabrik tetap :

$=\frac{\text { Jumlah anggaran biaya overhead pabrik tetap }}{\text { Jumlah jam standar }}$

$=\frac{\operatorname{Rp} 2.478 .404 .309}{2.016}$

$=\operatorname{Rp} 1.229 .367,217$

c) Tarif biaya overhead pabrik variabel

Tarif biaya overhead pabrik variabel:

$=\frac{\text { Jumlah anggaran biaya overhead pabrik variabel }}{\text { Jumlah jam standar }}$

$=\frac{\operatorname{Rp} 370.000 .000,00}{2.016}$

$=\operatorname{Rp} 183.531,746$

2) Analisis varians biaya overhead pabrik

a) Metode dua varian

Varians terkendali

- Biaya overhead pabrik aktual

- Anggaran

Biaya overhead pabrik tetap

Rp 2.478.404.309

Biaya overhead pabrik variabel 


$$
\begin{aligned}
& (\mathrm{Rp} 183.531,746 \times 2.016) \quad \frac{\mathrm{Rp} 370.000 .000+}{\frac{\mathrm{Rp} 2.484 .404 .309-}{\mathrm{Rp} 337.346 .678(\mathrm{M})}}
\end{aligned}
$$

Varians volume

- Anggaran Rp 2.848.409.309

- FOH disyaratkan (Rp 1.169.525,52 x 2.184) $\operatorname{Rp} 2.947 .204 .290$ Rp 98.799.981,24 (M)

b) Metode tiga varians

Varians pengeluaran

- FOH Aktual

- FOH disyaratkan

FOH tetap $\underline{\operatorname{Rp} 2.478 .404 .309+}$

FOH variabel

(Rp 183.531,75 x 2.184)

$$
\frac{\operatorname{Rp} 400.833 .333+}{\frac{\operatorname{Rp} 2.879 .237 .642}{\operatorname{Rp} 368.180 .011(\mathrm{M})}-}
$$

Varians kapasitas menganggur

- FOH disyaratkan

Rp 2.947.204.290

- FOH disyaratkan (2.184 x Rp 1.461.906,89)

Rp 3.192.804.648

$\overline{\mathrm{Rp}} 245.600 .358(\mathrm{M})$

Varians efisiensi

Varians efisiensi

$$
\begin{aligned}
= & (\text { jam kerja aktual }- \text { jam kerja standar yang } \\
& \text { dibebankan pada produksi }) \times \text { tarif } F O H \\
= & (2.016-2.184) \times \text { Rp. } 1.461 .906,89
\end{aligned}
$$

c) Metode empat varians

Varians pengeluaran

Varians Kapasitas Menganggur

Perhitungan varians pengeluaran dan varians kapasitas menganggur sama dengan perhitungan pada metode tiga varians di atas. 
Varians efisiensi tetap

Varians efisiensi tetap $\quad=$ (jam kerja aktual - jam kerja standar dijalankan) x tarif FOH tetap

$=(2.016-2.184) \times \operatorname{Rp} 1.229 .367,217$

$=\operatorname{Rp} 206.533 .692,4(\mathrm{M})$

Varians efisiensi variabel

Varians efisiensi variabel

$=($ jam kerja aktual - jam kerja standar dijalankan) $\mathrm{x}$ tarif $\mathrm{FOH}$ variabel

$=(2.016-2.184) \times \operatorname{Rp} 183.531,746$

$=\operatorname{Rp} 30.833 .333,33(\mathrm{M})$

d) Varians $\mathrm{FOH}$ total

- FOH Aktual

$\operatorname{Rp} 2.511 .057 .631$

- FOH disyaratkan $(\operatorname{Rp} 1.461 .906,89$ x 2.184) $\quad \underline{R p 3.192 .804 .648}$

Rp $681.747 .017(\mathrm{M})$

Dari perhitungan di atas dapat diketahui bahwa varian overhead pabrik total menguntungkan, yaitu sebesar Rp 681.747.017,00. Melalui perhitungan varians dengan menggunakan berbagai metode di atas dapat diketahui adanya selisih terkendali yang menguntungkan, selisih volume yang menguntungkan dan selisih efisiensi yang menguntungkan. Adapun adanya selisih tersebut disebabkan karena biaya overhead pabrik aktualnya lebih kecil daripada biaya overhead pabrik yang disyaratkan. 


\section{KESIMPULAN DAN SARAN}

\section{Kesimpulan}

Penerapan struktur organisasi PDAM Kabupaten Malang sudah berjalan dengan baik. Tanggung jawab dan wewenang dari masing-masing bagian atau unit sudah jelas. Hubungan kerja antara bagian yang satu dengan bagian yang lain juga sudah ditetapkan secara tegas.

Penyusunan anggaran yang dilakukan oleh PDAM Kabupaten Malang sudah melibatkan seluruh bagian dalam organisasi perusahaan.

Penerapan akuntansi pertanggungjawaban biaya produksi sebagai alat untuk menilai prestasi kerja manajer produksi dapat dilakukan dengan analisis varians yang meliputi varians bahan baku, varians tenaga kerja langsung, dan varians overhead pabrik.

\section{Saran}

Perusahaan hendaknya memisahkan biaya berdasarkan dapat tidaknya biaya tersebut dikendalikan. Hal ini dimaksudkan mempermudah manajemen untuk mengendalikan biaya yang menjadi tanggung jawabnya.

Pemberian kode rekening hendaknya disusun berdasarkan tingkatan manajemen yang ada pada struktur organisasi perusahaan.

Sistem pelaporan biaya yang dibuat secara periodik oleh perusahaan hendaknya benar-benar merupakan umpan balik dari wewenang dan tanggungjawab yang dilimpahkan oleh manajer pusat pertanggungjawaban. Sistem pelaporan biaya hendaknya dibuat sesuai dengan tingkatan manajemen struktur organisasi yang ada sehingga dapat dijadikan sebagai alat penilaian prestasi manajer produksi dalam perusahaan. 


\section{DAFTAR PUSTAKA}

Arikunto, S. 2002. Prosedur Penelitian: Suatu Pendekatan Praktis. Jakarta: PT. Rineka Cipta.

Anthony, Dearden, Bedford. 1992. Hakekat Pengendalian Manajemen. Dalam Maulana, Agus. Sistem Pengendalian Manajemen.

Baridwan, Zaki. 1998. Sistem Akuntansi: Penyusunan Prosedur dan Metode. Yogyakarta: YPFE.

Horngern, Charles, George Foster. 1991. Akuntansi Biaya: Suatu Pendekatan Manajerial. Jilid I. Jakarta: Erlangga.

Harnanto. 1992. Akuntansi Biaya: Perhitungan Harga Pokok Produksi. Edisi I. Yogyakarta: BPFE.

Hariadi, B. 1992. Akuntansi Manajemen: Suatu Pengantar. Yogyakarta: BPFE.

Matz, Adolph, Milton F. Usry. 1996. Akuntansi biaya: Perencanaan dan Pengendalian. Jilid 2. Jakarta: Erlangga.

Mulyadi. 1999. Akuntansi Biaya: Penentuan Harga Pokok dan Pengendalian Biaya. Yogyakarta: BPFE.

Nazir, Moh. 1999. Metode Penelitian. Jakarta: Ghalia Indonesia.

Sugiri, S. 1999. Akuntansi Manajemen. Yogyakarta. AMP YKPN.

Supriyono, RA. 1999. Akuntansi Manajemen: Konsep Dasar Akuntansi Manajemen dan Proses Perencanaan. Yogyakarta: BPFE. 